\title{
LOCAL DESIRE SATISFACTION AND LONG-TERM WELLBEING: REVISITING THE GOUT SUFFERER OF KANT'S GROUNDWORK
}

\begin{abstract}
In this paper, I analyze the least discussed of Kant's four examples of duty in the first section of his Groundwork to the Metaphysics of Morals: the gout sufferer who is no longer motivated by natural interest in his long-term wellbeing, and is thus in a unique position to secure his own happiness from duty. This example has long been wrongly interpreted as a failure of prudential rationality, as recently illustrated by Allen Wood's reading of that example.

I argue that the gout sufferer example is meant to illustrate a violation of a duty to the self and should not be confused with mere prudential failure. The example also helps us understand the line between prudential reason and duties to the self. I show that given Kant's conception of happiness as an indeterminate concept and his hedonistic account of non-moral ends, it can sometimes be more rational from the perspective of empirical practical reason to choose short term over longterm wellbeing when long term wellbeing seems uncertain in regard to expected pleasure. In other words: Kant's account of empirical practical reason does not rule out as irrational choosing short term pleasure at the expense of long-term wellbeing. However, this is precisely why the gout sufferer's long-term happiness can be directly morally required and so becomes the content of a duty to the self. To explain how there can be a direct duty to promote our own happiness under certain circumstances I also elucidate Kant's distinction between direct and indirect duties.
\end{abstract}

\section{Kant's general conception of practical reason}

Reconstructing Kant's general conception of practical rationality is a particularly difficult task. Kant's main project when he writes about practical reason is to give an account of the principle of morality and why it must be understood as a categorical imperative, as opposed to principles presupposing an existing desire of the agent. For the most part, Kant's account of non-moral rationality can be reconstructed only indirectly, that is, from what Kant says when he is primarily attempting to draw a contrast between moral and nonmoral practical reasoning and motivation.

Kant scholars have tried to reconstruct Kant's conception of practical rationality beyond his account of moral reasoning. Thomas E. Hill introduced the so called "instrumental principle" into the Kant literature ("whoever wants an end wants the necessary means"). ${ }^{1}$ Allen Wood suggested that it is possible

Thomas E. Hill, “The Hypothetical Imperative”, Philosophical Review 82 (4):429-450 (1973) 
to spell out a "principle of prudence", which requires rational agents to take the means not to an isolated end, as in the instrumental principle, but to our happiness as a whole. Wood formulates this principle as follows: "use your reason, understanding and imagination to form for yourself a more determinate idea of the greatest attainable total satisfaction of your inclinations (under the name of 'happiness'); and give first priority, among all your non-moral ends, to happiness, preferring it to all other non-moral ends when they conflict with it." 2

Allen Wood's main project is to draw a clear cut distinction between instrumental and prudential rationality. As Wood notes, Kant did not keep this distinction clear in the Groundwork and attempts to reduce prudential reason to mere instrumental rationality; further, he argues that Kant's conception of prudence is incoherent, in contrast to his conception of instrumental reason, which can be reconstructed into a cogent account. ${ }^{3}$ Wood's aim is to provide a modified interpretation that can offer a "minimally coherent story" about prudential reason. He suggests reading the gout sufferer example as a failure of prudential rationality. Further, he makes the case for interpreting prudential reason as a distinctive kind of rationality, as opposed to mere instrumental reasoning. Kant, Wood argues, often gives the impression that what is wrong with the gout sufferer is that he fails to take the necessary means to his happiness; however prudential rationality, if considered a distinctive kind of practical rationality, would consist in giving the end of happiness an absolute priority over other isolated non-moral ends and immediate desires (constrained only by morality). Therefore, in Wood's interpretation the gout sufferer is imprudent because he fails to assign happiness priority over his immediate inclination:

Kant's imprudent gout sufferer (GMS 4: 399), for instance, knows perfectly well the means to open the liquor cabinet and get at the brandy he desires, and also the means to keep his gout from acting up - namely, to leave the liquor cabinet alone and lay off the brandy. What he needs to constrain himself to do, through the exercise of prudential reason, is to give priority to the end of his happiness (satisfaction with his life as a whole) over the short term end of satisfying a momentary impulse the indulgence of which will later leave him much unhappier. So it gets prudential reason basically wrong to focus, as Kant does, on the possible hypothetical imperatives that might be involved in pursuing the end of one's happiness. (Wood, "Kant on Practical Reason", p. 73)

2 Allen Wood, "Kant on Practical Reason". In: Mark Timmons and Sorin Baiasu, Kant on Practical Justification: Interpretive Essays (OUP 2013). A related debate in Kant scholarship is whether we should take these principles to be normative or merely descriptive. The reason for scepticism about the normativity of the non-moral principles of rationality is based on Kant's claim that the hypothetical imperative is analytic (GMS IV: 217) and that there are no pragmatic imperatives, only counsels of prudence (GMS IV: 418). Kant's formulation "whoever wills the end wants the necessary means" also suggests a merely descriptive principle. For positions who deny that the instrumental principle is normative see Bernd Ludwig, „Warum es keine „hypothetischen Imperative“ gibt“, In: Klemme, Ludwig, Pauen and Stark (eds.) Aufklärung und Interpretation. Studien zu Kants Philosophie und ihrem Umkreis. Königshausen \& Neumann, 1999.

3 Wood, "Kant on Practical Reason", p. 69. 
Was Kant merely confused in this example about what is prudent and what is moral? Did Kant fail to recognize prudential reason as a distinctive kind of practical rationality? I will argue in this paper that the gout sufferer example illustrates a violation of a duty to the self rather than a prudential interest. Kant's refusal to accuse the gout sufferer of prudential irrationality is significant, and has not been acknowledged enough in the literature. As Kant stresses in the text, the principle enjoining the gout sufferer to secure his health is the moral law, not prudential reason: "there still remains a law, namely to advance one's happiness, not from inclination, but from duty, and it is not until then that his conduct has its actual moral worth. (GMS IV: 399, my emphasis)."4 In this paper I will take seriously the fact that Kant did not criticise the gout sufferer for prudential irrationality and draw some conclusions about the nature of prudential reason in Kant's account. Further, I will analyse the distinction between direct and indirect duties, and show that it is central for understanding how and when securing one's happiness can become the object of a direct duty to the self, despite Kant's claim that there can be no duty to promote one's own happiness.

\section{The Gout Sufferer of the Groundwork: imprudent or immoral?}

In the Second Critique, Kant identifies both desire satisfaction and our interest in prudence with the principle of one's own happiness or self-love (KpV $\mathrm{V}$ : 22). This suggests that there is no relevant difference between the two. As Kant notes, "the principle of one's happiness, however much understanding and reason may be used in it, still contains no determining ground of the will other than such as is suitable to the lower faculty of desire" (KpV V: 24). However, in the Groundwork Kant draws an explicit contrast between the gout sufferer's immediate desire to indulge in food and drink and the "general inclination to happiness" (allgemeine Neigung nach Glückseligkeit). What can the gout sufferer of the Groundwork teach us about Kant's conception of prudence?

To secure one's own happiness is one's duty (at least indirectly) [wenigstens indirect]; for lack of contentment with one's condition, in the trouble of many worries and amidst unsatisfied needs, could easily become a great temptation to transgress one's duties. But, even without taking note of duty [auch ohne hier auf Pflicht $z u$ sehen], all human beings have already of their own the most powerful and intimate inclination to happiness, as it is just in this idea that all inclinations unite into one sum. (IV: 399)

What does Kant mean by "securing one's happiness" (seine eigene Glückseligkeit sichern) in the above passage? As Kant notes, "lack of contentment

4 „Aber auch in diesem Falle, wenn die allgemeine Neigung zur Glückseligkeit seinen Willen nicht bestimmte, wenn Gesundheit für ihn wenigstens nicht so nothwendig in diesen Überschlag gehörte, so bleibt noch hier wie in allen andern Fällen ein Gesetz übrig, nämlich seine Glückseligkeit zu befördern, nicht aus Neigung, sondern aus Pflicht, und da hat sein Verhalten allererst den eigentlichen moralischen Werth." (GMS IV: 399) 
with one's condition, in the trouble of many worries and amidst unsatisfied needs, could easily become a great temptation to transgress one's duties." The moral reason for securing our happiness is thus to make us less susceptible to temptations arising from unsatisfied needs and general discontentment with one's life. We must take into account and avoid possible impediments to morality arising from human nature. This view presupposes the assumption that humans can achieve a certain level of satisfaction, sufficient to enable them to comply with moral commands. From this, it is possible to infer that Kant is thinking of happiness in the sense of one's overall, long term wellbeing, as opposed to the satisfaction of isolated, immediate desires. Happiness as overall, long term wellbeing will include a certain level of health, wealth and agreeableness in one's life (KpV V: 93, MS VI 388 and 432). How much wellbeing is necessary is presumably an individual question which cannot be settled in advance for all agents. ${ }^{5}$ Although happiness in this sense is far from being an uninterrupted state of satisfaction, where all needs and inclinations of the agent are satisfied (GMS IV: 405), it will ensure that the agent has a minimal amount of contentment in her life to ensure her ability to respond to rational requirements.

However, in other passages Kant suggests that the moral significance of happiness is not restricted to being a mere means to morality. A certain degree of agreeableness in life can be seen as something owed to oneself, as a rational being who also possesses an animal nature, and consequently has needs. In MS VI: 432, Kant criticizes the miser for restricting her enjoyment of the means to good living to the point of leaving her true needs unsatisfied. It is important to note that the argument is not that miserliness amounts to a violation of a duty to others (although the miser certainly fails in this too). Her moral failure consists instead of voluntarily depriving herself of the permissible joys and comforts of life, despite having the necessary means. The miser is primarily violating a duty to the self. ${ }^{6}$

As Kant stresses in the quoted passage, securing one's happiness is one's duty at least indirectly (wenigstens indirect). ${ }^{7}$ What does it mean for a duty to be "at least" indirect? In answering this question, we must first consider what an indirect duty is. Very little work has been done on the notion of indirect duties in Kant. ${ }^{8}$ In the following, I will offer an interpretation of indirect duties in which "indirectness" refers to the impossibility of direct moral motivation, that is, of action from duty.

As the term 'indirect' suggests, indirect duties presuppose the assumption that some duties can be directly commanded. More precisely, what can be directly

5 Cf. MS VI: 395, where Kant identifies happiness with one's true needs and argues that one must decide for oneself "in view of one's sensibilities" how much to contribute to the happiness of others.

6 Cf. also MS VI: 420, where preserving one's natural capacity for enjoying life is said to be an end of nature human beings must not violate for arbitrary reasons.

7 Cf. KpV V: 93 ll. 15-9.

8 See Alix Cohen, Kant and the Human Sciences. Biology, Anthropology and History. Palgrave Macmillan, 2009, and Jens Timmermann, 'Kant on Conscience, Indirect Duty and Moral Error', International Philosophical Quarterly, vol. 46, no3 Issue 183, September 2006. 
commanded is the omission or performance of a specific action (when acting otherwise would violate a duty) or the adoption of a specific moral maxim or moral end. ${ }^{9}$ The agent is able to follow the command out of respect for the law, that is, her motive for the action is duty.

Kant makes several scattered remarks about indirect duties without ever defining them in greater depth. Examples of indirect duties in Kant's works are for instance, natural predispositions to be emotionally affected by the moral law (what he calls "conscience" or "moral sense"), natural feelings and inclinations of human beings, which can facilitate and support moral agency (natural sympathy or love of humanity; sensitivity to the pain of animals and beauty in nature). Securing one's own happiness is an indirect duty, while adopting the happiness of others is a direct duty. ${ }^{10}$

Indirect duties have a general common trait: they involve some natural feature of human beings that we can neither create nor manipulate at will, although these natural features may allow cultivation for our moral purposes. Although complying with indirect duties may be seen as the expression of an agent's commitment to moral principles, it is distinctive of indirect duties that all we can do is to consciously allow ourselves be moved by certain natural feelings, which we neither create nor can invoke at will. ${ }^{11}$ Securing one's happiness is an indirect duty because Kant assumes that all human beings want their happiness as a matter of fact. And what we already want cannot be commanded as one's duty (and I shall add, at least not as one's direct duty).

A different interpretation, proposed by Jens Timmermann, explains indirect duties as not being duties proper, i.e. as not binding "in their own right," as opposed to the categories of perfect and imperfect duties. ${ }^{12}$ Although it is a matter of duty to do what is commanded, the injunction of indirect duties is only accidental, as means to the realization of a directly commanded moral end. Indirect duties are not generated by the categorical imperative alone, but also require instrumental reasoning. It follows that complying with indirect duty does not have any moral worth "as such", only as a means to a direct duty. As Timmermann rightly stresses, indirect duties express our concern with the effectiveness of moral agency, which is that we be able to bring about what the

9 This corresponds to direct and indirect duties respectively.

10 For a very useful summary of Kant's scattered remarks on indirect duties, see Alix Cohen, Kant and the Human Sciences. Biology, Anthropology and History. Palgrave Macmillan, 2009, p. 92.

11 The interpretation of indirect duties I have put forward regards the objects of indirect duties as those dispositional or emotional states which exclude the possibility of direct moral motivation, because the disposition or emotion in question can only be naturally given. If a non-moral disposition happens to coincide with what duty commands, indirect duty does not command that it be suppressed or replaced by the moral motive. My view is that its presence is desirable insofar as it excludes the presence of inclinations contrary to duty, which could tempt us to act otherwise as reason commands.

12 Jens Timmermann, Kant's Groundwork of the Metaphysics of Morals. A Commentary. Cambridge University Press, 2007, p. 36. See also Timmermann, 'Kant on Conscience, Indirect Duty and Moral Error', International Philosophical Quarterly, vol. 46, no3 Issue 183, September 2006. 
motive of duty alone may not be able to effect, given the limitations and "frailty" of human nature (MS TL VI: 456-7). Kant's notion of indirect duties is therefore evidence that his moral theory is not indifferent to the consequences of moral endeavours. ${ }^{13}$ However, the problem with this interpretation is that it creates more indirect duties than Kant himself acknowledges. To identify whatever is a necessary means to moral ends with indirect duties as Timmermann suggests, would imply that all hypothetical imperatives we need to follow in order to realize our duty in the world would have to be considered indirect duties: for example, if my helping you out of a pond requires taking off my shoes, I would have an indirect duty to take off my shoes. However, this is not only incorrect but also unnecessary, since according to Kant, to have an end analytically implies the commitment to take the necessary means to that end (GMS IV: 417). Since the requirement to take the means is analytically implicit in the notion of willing an end, there is no need to posit further duties to take the necessary means to fulfil one's duty.

Conflating indirect duties with means to direct duties overshadows the real function of indirect duties and why Kant saw fit to posit them. They are indirect because it is not possible to feel or love or have a natural disposition on command ( $\mathrm{KpV} \mathrm{V}: 83)$. The feelings or dispositions in question can only be naturally given. ${ }^{14}$ As Kant stresses, an imperative is a rule the representation of which makes necessary an action that is subjectively contingent; the subject must therefore be constrained (necessitated) to conform to the rule (MS VI: 222). But we cannot be constrained to something we already want or are naturally disposed to. When the object in question is morally relevant (in this case, when it can reduce possible obstacles to moral agency), is a naturally given disposition or feeling, and cannot be activated on command, we have an indirect duty to cultivate, develop or realize it, as far as possible. This is the case, for instance, of sympathetic feelings towards others. While one should not let sympathy become the one's motive when helping others (respect for the law must be this motive), sympathy nevertheless makes compliance with duty easier by avoiding struggle and the temptation to disregard the moral law.

Kant's formulation in the gout sufferer passage implies that securing one's happiness can nevertheless become the object of a direct duty. This is only possible if one can cease to be motivated by natural interest in one's own happiness, and replace it with duty as a motive. Although Kant claims that happiness is an end of human beings according to a natural necessity (nach einer Naturnothwendigkeit, GMS IV: 415-6), the gout sufferer example of the Groundwork makes clear that Kant differentiates the general desire for happiness from the wish to satisfy a single inclination, when this inclination is incompatible with one's long term wellbeing.

13 It is important to stress that indirect duties do not guarantee successful actions, only a successful determination of the will by the moral law (given the lack or reduction of temptations against duty). The consequences of the agent's successful determination of the will are thus secondary, because they depend on contingent factors external to the will.

14 As I shall explain, this does not always apply to the duty to promote one's happiness. 
However, I will argue that in the long term wellbeing is assigned no independent value in Kant's theory of practical reason. The neglect of one's overall wellbeing for the sake of a single inclination only becomes a problem because the neglect of one's overall, long term happiness has a bearing on moral agency and/or on the agent's dignity as a person. The agent is thus required to secure her wellbeing out of duty. It follows that the indirect duty to secure one's happiness differs from the other indirect duties I have mentioned because it also qualifies as a direct duty under specific circumstances. Should we fail to be motivated by the natural inclination to secure our long term happiness, we then have a direct duty to secure at least the minimal conditions of our wellbeing, since failing to do so would imply a violation of a duty to the self. ${ }^{15}$ This is what I will attempt to show in the next two sections.

\section{Empirical Practical Reason and the indeterminacy of Happiness}

...the prescription of happiness is predominantly such, that it greatly infringes on some inclinations and yet human beings can form no determinate and reliable concept of the sum of the satisfaction of all under the name of happiness; which is why it is not surprising that a single inclination - if determinate in regard to what it promises, and to the time its satisfaction can be obtained - can outweigh a wavering idea, and that a human being, e.g., someone suffering from gout of the foot, can choose to enjoy what he fancies and to suffer what he can, since, according to his calculation, at least then he has not denied himself the enjoyment of the present moment because of possibly groundless expectations of some good fortune (grundlose Erwartungen eines Glücks) that is meant to lie in health. (GMS IV: 399, my emphasis)

Kant has a complex conception of happiness, which he does not discuss openly in his works. As previously mentioned, Kant's main goal is to develop his moral theory. He therefore develops his conception of empirical practical rationality passim, only as far as required for this aim. His conception of happiness receives a similar treatment in his ethical works. A central trait of Kant's conception of happiness is that happiness is an indeterminate concept. Although every human being strives for happiness, no one is able to determine with certainty "and in agreement with himself what he actually wishes and wants" (GMS IV: 418). There are two different sources of the indeterminacy of happiness, both due to our cognitive limitations as finite rational beings. The first limitation is that we cannot foresee all the external consequences of the achievement of an end and their impact on our happiness. Our desire for an end is based on our conception of expected results and not on a complete knowledge of all possible outcomes. The other source of indeterminacy is that we don't even know our own desires with certainty. We must form a conception of our own happiness by means of our beliefs about what would make us happy and about what we think we want. Our only means to define what we want is by reference to our feelings of pleasure or displeasure in the representation of an object

15 As we shall see, this is not the duty to secure one's wellbeing per se, but in fact the duty to protect the conditions of moral integrity and agency. 
or condition (see KpV V: 21 and MS VI: 211). However, pleasure and displeasure involve "what is merely subjective in the relation of our representation and contain no relation at all to an object for possible cognition of it (or even cognition of our condition)". (MS VI: 211, my emphasis).

Let us now return to the gout sufferer. As Kant states in the passage, he does not know for sure if health will make him happy: his „expectations of some good fortune that is meant to lie in health", he calculates, could well be groundless. Having adopted an excessive, unhealthy lifestyle for a long time, restoring his health would involve drastically changing his eating and drinking habits and foregoing many pleasures. Even if he ever succeeds in restoring his health to some extent, it may never be very pleasant again. Making sacrifices for the sake of one's health may not make much sense anymore. What could possibly motivate the gout sufferer to make such an effort? Kant assumes that there are only two types of motivation: duty (respect for the moral law) or inclination, which Kant identifies with self-love, and consequently with the desire for one's own happiness. In the latter case, "it is not the form of lawfulness that counts but simply the matter, namely whether I am to expect satisfaction from following the law, and how much" (KpV V: 25-6, my emphasis). In other words, Kant assumes that non-moral motivation is hedonistic. ${ }^{16}$

It is outside the scope of this paper to examine the plausibility of Kant's conception of non-moral motivation. For the purposes of the paper, I will take Kant's hedonism about non-moral motivation for granted, and analyse its implications for the relationship between prudence and duties to the self. If we set aside moral motivation, the only motive the gout sufferer could have for promoting his health is expectation of pleasure or the desire to avoid pain. However, he is aware that restoring his health will be toilsome, and that the rewards in terms of expected pleasure are uncertain. From the perspective of empirical practical reason, it is perhaps not worth the effort. It might be better just to eat and drink what he can and to suffer afterwards (assuming that some pain will be inevitable whatever he does). It follows that from the point of view of expected pleasure, it is not irrational for the gout sufferer to sacrifice his health for his immediate desire for food and drink. This is because considering his particular circumstances, satisfying a single actual desire is more likely to bring pleasure than the "wavering" promise of long-term wellbeing. I also assume that the gout sufferer has also considered the amount of pain involved in either restoring his health or indulging in his desire for food and drink. Even though he is aware that physical pain will follow from indulging himself, he is more willing to put up with pain that follows as a result of his indulgence than with the discomfort of having to forego pleasures and change his lifestyle. ${ }^{17}$

16 There is enough textual evidence confirming that Kant explicitly adopted hedonism about non-moral ends. See for instance KpV V: 22, 23 ll. 25-39. However, there is disagreement in the literature about whether Kant should be read in that way. For a non-hedonistic interpretation of Kant's account of empirical practical reason, see Andrews Reath, „Hedonism, Heteronomy and Kant's Principle of Happiness". In: Agency and Autonomy in Kant's Moral Theory, Oxford University Press, 2006.

17 Although one could question the rationality of such a preference, it seems at least psychologically plausible to assume that agents can be more disposed to put up with pain as the result of enjoying life than with the restrictions required by a healthy life style when 
While happiness as long term satisfaction is uncertain for the gout sufferer, immediate desire satisfaction seems less uncertain to him. Whether this is truly the case no one can know for sure, since this would require omniscience (GMS IV: 418). It could be that the meal turns out to be disappointing, or that the unexpected heart burn after the brandy by far outweighs the pleasure one had in drinking it. However, satisfying a desire that is closer in time and more determinate in scope can seem, at least psychologically, more certain to the agent than investing one's energy in a long-term, general state of wellbeing (her health) when the agent's health is already compromised to the extent that she can only avoid increasing pain, but will severely restrict what she considers positively enjoyable.

Kant assumes that most agents are naturally inclined to promote their overall wellbeing or happiness. This is why it is needless to posit a duty to pursue one's own happiness. However, as the gout sufferer illustrates, it is possible that agents come to lack or simply disregard the concern for long term happiness that most people naturally have. ${ }^{18}$ Surprisingly, Kant argues that the gout sufferer has a duty to promote his health. When promoting his health in the absence of an inclination to it, the conduct of the gout sufferer acquires moral worth. Is Kant confusing a maxim of prudence with a moral duty?

I will argue that Kant implicitly distinguished between an objective and a merely subjective conception of happiness. While the objective conception includes the basic ends of our animal nature which have an impact on our moral integrity and which can be directly commanded in case of neglect, the subjective conception of happiness is dependent on the agent's conception of her desires and needs. Although the latter may coincide in content with the objective conception of happiness, this coincidence is merely contingent. We usually adopt the basic ends of human animal nature from inclination, and not duty. This is what Kant calls our "general inclination for happiness", allgemeine Neigung nach Glückseligkeit. However, we cannot arbitrarily choose to neglect these ends without violating morality.

\section{Happiness and Duties to the Self}

But also in this case, if the general inclination to happiness [allgemeine Neigung nach Glückseligkeit] did not determine [the gout sufferer's] will, if health, at least for him, did not enter his calculation so necessarily, then here, as in all other cases, there still remains a law, namely to advance one's happiness, not from inclination, but from duty, and it is not until then that his conduct has its actual moral worth. (GMS IV: 399 , my emphasis $)^{19}$

no pleasures, or at least absence of discomfort, are in sight. However, one may feel scared of the consequences of deteriorating health and the possibility of a shorter life. In this case, the agent would have an inclination which could provide a strong enough motive to change one's lifestyle. Fear of death does not enter the gout sufferer's calculations at that stage.

18 A similar example is the miser in the Doctrine of Virtue (MS TL VI: 432-3) which I discuss below.

19 „Aber auch in diesem Falle, wenn die allgemeine Neigung zur Glückseligkeit seinen Willen nicht bestimmte, wenn Gesundheit für ihn wenigstens nicht so nothwendig in diesen Überschlag gehörte, so bleibt noch hier wie in allen andern Fällen ein Gesetz übrig, nämlich 
As Kant surprisingly remarks in the Critique of Judgment, our species is in complete consensus (durchgängig mit sich übereinstimmt) in regard to genuine natural needs of human beings (wahrhafte Naturbedürfniß, KU V: 430). However, there can be no categorical imperative commanding us to include these natural needs in one's subjective conception of happiness, since most people are already naturally inclined to adopt these ends (in which case it cannot be a duty to adopt them). From the perspective of happiness there can be no prudential imperative to adopt these ends either, since there is no guarantee that these ends will make us happy. Telling someone that it would be prudent for her to adopt a certain end (say, that she should save money) is merely giving advice (Rathgebung) in the assumption that the person has included certain ends in their conception of happiness and would thus have a reason to follow our counsels. Therefore, a counsel of prudence contains necessity (Nothwendigkeit) or normative force only for those agents who already want the end in question, given their conception of happiness (GMS IV: 416), but not for those who have a different conception of happiness.

In his account of the vice of intemperance in the Metaphysics of Morals, Kant stresses that "the reason for considering this kind of excess a vice is not the harm or bodily pain (diseases) that a human being brings on himself by it; for then the principle by which it is would be one of well-being and comfort (and so of happiness), and such a principle can establish only a rule of prudence (Klugheitsregel), never a duty - at least not a direct duty" (MS VI:427). Although rules of prudence do not give rise to duties, the object of rules of prudence can nevertheless coincide with the content of certain direct duties (as I will argue, these are duties to the self). In this case, the ends recommended by prudence may either be the object of an indirect duty (when we have an inclination for the end anyway and consequently cannot be necessitated to act by an imperative of duty) or the object of a direct duty (when we lack the inclination for the end and the end can be directly commanded, as in the case of happiness).

One may eat healthily and exercise regularly not out of duty, but because one is afraid of having a stroke or a heart attack, or simply is afraid of pain or death. However, good health also belongs to those genuine natural ends all finite rational beings ought to care about for moral reasons. If, similarly to the gout sufferer, one no longer cares to maintain one's health because some short term pleasure seems more likely to bring satisfaction, morality can command directly that one secures one's health instead of indulging in shortterm pleasure. Then the agent would be securing her health out of respect for the moral law and her conduct would have moral worth. Prudence would only have a say for such an agent if she still happened to have an inclination for her overall happiness, in which case the counsels of prudence would only "remind her" of what she already wants, namely, her overall, long-term wellbeing, and the satisfaction of some particular inclination may be inconsistent with her long-term wellbeing.

seine Glückseligkeit zu befördern, nicht aus Neigung, sondern aus Pflicht, und da hat sein Verhalten allererst den eigentlichen moralischen Werth." (GMS IV: 399) 
The line between duties to oneself and rules of prudence is a very subtle one. Kant stresses that violations of duties to the self at first glance often seem a matter of imprudence rather than proper vices. Kant makes this worry explicit in the case of the vice of stupefying oneself by excessive drink and food (MS VI: 426) and the maxims of prodigality and miserliness (MS VI: 434). However, the rationale of the duty is not primarily the harm or bodily pain caused by such vices. There are two ways in which actions can be regarded as violations of duties to the self. I shall therefore distinguish between an instrumental and a constitutive argument for perfect duties to the self as an animal and moral being.

In the case of gluttony, drunkenness and drug addiction, it is usually the impairment of our ability to use our capacity for sensible enjoyment which makes these actions vices. This is why the enjoyment of alcohol to the extent that it stimulates conviviality and conversation should not be regarded as a vice (MS VI: 428). The idea is that, since an enjoyment is just one subjective end among others, it should neither hinder the pursuit of the other ends of the agent nor impair the use of her rational capacities. The agent's capacity to set herself ends is what enables the pursuit of particular ends; choosing ends that undermine this capacity is self-contradictory and a perversion of one's ability of non-moral choice in general. This is morally relevant inasmuch as the way we dispose of our ability to choose in non-moral matters also has an impact on our ability to act morally. In other words, these vices ultimately impair us as moral agents, temporarily or permanently. More importantly, the way we treat our ability of non-moral choice also expresses respect or disrespect for the humanity in our person. The requirement to respect humanity in everyone's person (including one's own person) imposes constraints on possible uses of our non-moral capacities.

This view is confirmed by Kant's claim in his lectures that drunkenness may be considered morally objectionable even if the agent does not harm herself physically (for instance, when she is very strongly constituted, Moral Collins, XXVII: 341). If a drunkard does not harm others and cannot harm herself, is drunkenness still a vice? Since Kant grounds duties to the self independently of the agent's relations to others, it is possible to violate a duty to the self even when no one is affected (not even the agent herself in her ability to comply with duties to others). Timmermann thus calls duties to the self "desert-island duties." ${ }^{20}$ In this case, it is our moral personality alone which prohibits drunkenness as a use of our person. Since certain uses of our person imply reducing ourselves to mere impulses and inclinations, they are incompatible with the agent's self-esteem (MS VI: 435). No instrumental connection between the omission of an action and our capacity for moral agency is required: omitting certain actions can be identical to the preservation of the agent's dignity or self-esteem. I conclude that the rationale of duties to self is ultimately the humanity in the person of the agent, and not merely the preservation of her capacity of rational agency.

20 Timmermann, 'Kantian Duties to the Self, Explained and Defended', Philosophy, 81, p. 508. 


\section{Conclusion: Prudential Reason in Kant's ethical theory}

There is a clear parallel between the gout sufferer example and the suicide example in GMS IV 397. Both examples concern things that are naturally dear to us: the preservation of our lives and our own happiness. In both examples, the natural inclination in question fails to motivate us: the depressed person wishes to put an end to her life; the gout sufferer chooses to disregard his health for the sake of actual enjoyment. Both are motivated by the gratification expected from an immediate inclination (the desire to put an end to one's distress and the desire to continue to have a pleasurable existence despite one's sickness). In both cases, Kant derives a direct moral obligation to preserve one's life and one's health.

Kant states that if we could know for certain what will make us happy, the counsels of prudence would turn into rules of skill (GMS IV: 417). Therefore, even if happiness was not an indeterminate concept, it would still not be the source of categorical requirements to take the means to our happiness. While the distinction assertoric / problematic concerns the question whether the end in question is actual or merely possible for an agent, the distinction hypothetical / categorical concerns the kind of necessitation of the rational principle in question: whether the principle is binding given the end one happens to have or could have, or binding independently of any inclinations or ends of the agent. Instrumental reason and prudence both give rise to hypothetical imperatives because their binding force is always conditional on the presence of an inclination or end. In contrast, only pure practical reason can give rise to categorical commands. Its necessity is derived from its rational, i.e. universal character. While one can identify three forms of practical reason, there are only two ways in which a principle can be binding: either categorically or hypothetically. Tertium non datur.

As beings aware of our existence over time, we can represent ourselves in the future. We are also aware that satisfaction with our condition does not last and consequently form the desire to extend the duration of satisfaction over time. This is why prudence can be normative to us: it tells us how to extend and possibly maintain a certain amount of satisfaction with our condition beyond immediate desire satisfaction. Prudential reason has a broader scope than instrumental reason: it must encompass our future selves, and for this it must take into account the ends we have now and possible ends we may have in the future. It requires that we plan and coordinate the satisfaction of our different non-moral ends over time, determine which ends have priority, and give up ends when compatibility is not possible. This is the sense in which prudential reason is not mere instrumental reason: simply taking the means to satisfy whatever desires we happen to have in the present does not guarantee satisfaction in our future condition; more needs to be achieved to ensure that contentment obtains in the future. Among other things, we try to avoid foreseeable hardships and provide the means to the satisfaction of our future ends: we try to keep healthy, we study for a degree, save money and so on. Prudential reason can be seen as a normative standard of rationality, but only if the agent has an inclination for her long term happiness, that is, if she expects satisfaction from it. This is the sense 
in which prudence can be said to give rise to hypothetical imperatives, in the same way as instrumental reason.

It follows that empirical practical reason as Kant conceives it cannot always command that long-term happiness be given absolute priority over other nonmoral ends. From the perspective of empirical practical reason, what ensures the priority of long-term happiness is overall expectation of pleasure. Our reason to be prudent is thus that it promises more pleasure in the long run than indulging in immediate desires. However, depending on the circumstances, prudence does not always result in more pleasure, and we can foresee that. This is precisely the realization of the gout sufferer. But this is also why the gout sufferer is in the unique position to secure his own happiness out of respect for the moral law, and Kant's point in using this example to illustrate action from the motive of duty. It is important to note that acting from duty does not render happiness less indeterminate; it could well be that happiness will follow from securing his health. However, this is only a problem for prudential reason, and not for morality: while prudence only makes sense if securing our health will in fact make us happy, for morality what matters is that we have done the right thing from the right motive. In the gout sufferer's case, that he not reduce his animal nature to the pleasures of the moment, and treat his own person in a way compatible with his dignity and rational nature. ${ }^{21}$

21 I would like to thank the participants of the Irish Philosophical Club 2016 for their enthusiasm and very helpful questions and comments on this article, in particular Jim O'Shea, Jim Levine, Adam Loughnane, Markus Schlosser, Elmar Geir Unnsteinsson, Sean Enda Power and Jason Dockstader. I would also like to thank an anonymous referee of the Kantian Review for very encouraging and helpful feedback on an earlier version of this article. 